\title{
Analisa Simulasi Sistem Antrian Pada Suatu SPBU
}

\author{
Jamaluddin \\ Program Studi Manajemen, STTI
}

Email: nasutionjamaluddin@yahoo.com

\begin{abstract}
ABSTRAK
Ketika para pelanggan/konsumen harus menunggu untuk mendapatkan jasa pelayanan, maka keberadaan sistem antrian sangat diperlukan. Beberapa contoh berikut ini menunjukkan bahwa penggunaan sistem antrian sangat membantu dalam melancarkan pelayanan kepada pelanggan atau konsumen. Dalam bab berikut akan kita bicarakan salah satu cabang dari manajemen yang secara umum menyangkut fenomena dalam hal: "Konsumen atau pelanggan menunggu untuk mendapatkan jasa pelayanan".

Di samping itu juga akan kita bahas berbagai macam struktur model antrian yang telah diakui, karakteristik model antrian, dan contoh aplikasi dalam menentukan jumlah kasir bank untuk mengurangi waktu tunggu para pelanggan. Untuk bab berikut ini, marilah kita membahas masalah antrian di SPBU di mana mobil mengisi bahan bakar.
\end{abstract}

Keywords: Platen Tube Superheater, Leakage, Non - Destructive Test, Pearlite, Boiler 
PENDAHULUAN

Struktur Sistem Antrian.

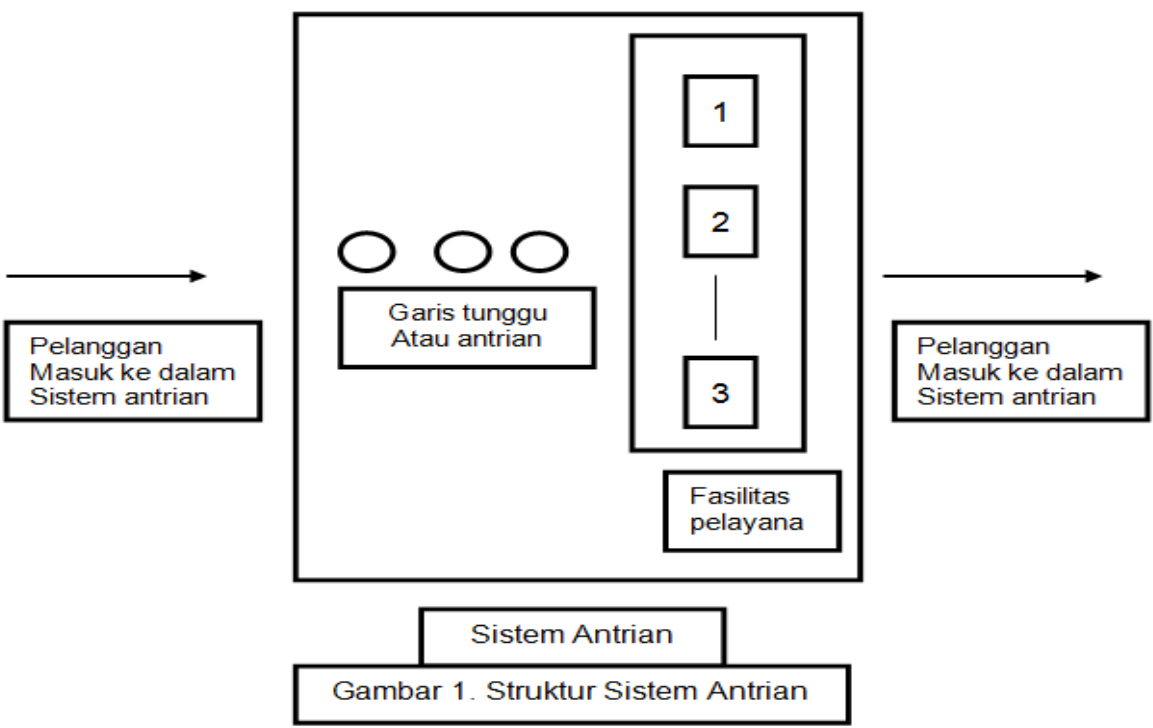

Dalam gambar 1 menunjukkan struktur umum dari model antrian yang memiliki dua komponen utama yaitu : (1) Garis tunggu atau sering disebut antrian (queue), dan (2) Fasilitas pelayanan (Service facility),
Pelanggan atau konsumen menunggu untuk mendapatkan jasa pelayanan. Setiap pelanggan menunggu giliran untuk memasuki fasilitas pelayanan, menerima pelayanan, dan akhirnya keluar dari sistem pelayanan.

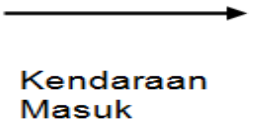

Masuk

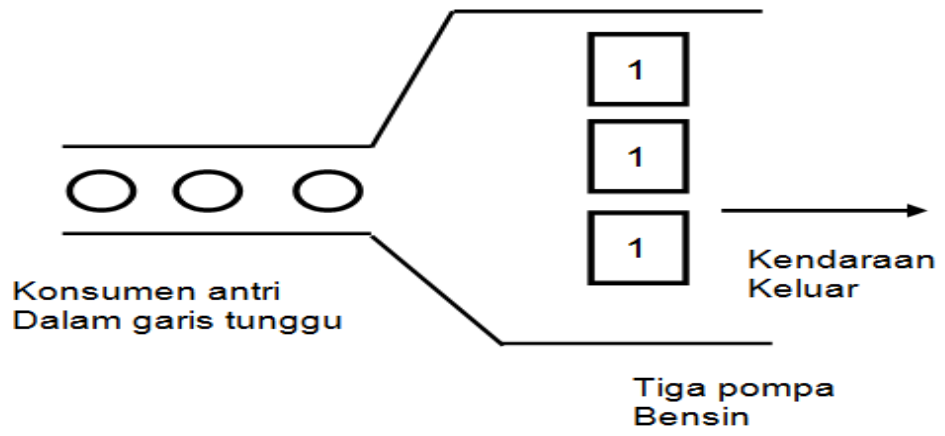

Sistem Antrian

Gambar. 2 di SPBU
Contoh yang tepat untuk menggambarkan keadaan ini adalah pelayanan pengisian bahan bakar dan stasiun pengisian bahan bakar umum (SPBU) atau sering disebut pombensin. Seandainya sebuah SPBU memiliki tiga pompa bensin dengan satu garis tunggu, seperti ditunjukkan olehGambar 2 dengan asumsi bahwa setiap pelanggan yang datang lebih awal akan dilayani lebih dulu (first come-first served). Pemilihan bagaimana model sebuah sistem antrian adalah sangat penting dalam 
mencapai keberhasilan aplikasi model antrian. Dalam contoh Pombensin di atas mungkin kita akan mengatakan bahwa akan lebih realitis apabila garis tunggu kendaraan tidak dalam bentuk garis tunggal, tetapi garis tunggu dilakukan untuk setiap pompa bensin. Di samping itu untuk meningkatkan kapasitas pelayanan, mungkin lebih baik menggunakan satu pompa untuk premium, satu pompa untuk premix dan satu pompa untuk solar.

\begin{tabular}{|c|c|}
\hline Sistem & Garis tunggu atau antrian \\
\hline 1. Lapangan terbang & $\begin{array}{ll}\text { Pesawat } & \text { menunggu } \\
\text { dilandasan } & \end{array}$ \\
\hline 2. Bank & Nasabah (orang) \\
\hline 3. Pencucian mobil & Mobil \\
\hline 4. Bongkar muat barang & Kapal dan truk \\
\hline 5. Sistem komputer & Program komputer \\
\hline $\begin{array}{l}\text { 6. Bantuan pengobatan } \\
\text { darurat }\end{array}$ & Orang \\
\hline 7. Perpustakaan & Anggota perpustakaan \\
\hline 8. Registrasi & Mahasiswa \\
\hline Mahasiswa & \\
\hline $\begin{array}{l}\text { 9. Skedul sidang } \\
\text { pengadilan }\end{array}$ & $\begin{array}{l}\text { Kasus yang } \\
\text { disidangkan }\end{array}$ \\
\hline
\end{tabular}

Dalam Tabel 1 dapat dilihat beberapa. daftar sistem antrian yang lain, sekaligus identifikasi dari item dalam antrian dan fasilitas pelayanan yang diperlukan. Contoh lain yang tidak termasuk dalam daftar tersebut adalah para pelayanan mendatangi konsumen, seperti unit pemadam bahaya kebakaran.

\section{Langkah-langkah dalam Analisa Antrian.}

Secara umum prosedur dalam mengerjakan teknik antrian adalahsebagai berikut:

$\begin{aligned} \text { Langkah } 1 \quad \text { : } & \text { Tentukan sistem } \\ & \text { antrian apa yang harus } \\ & \text { dipelajari. }\end{aligned}$

Langkah 2 : Tentukan model antrian yang cocok dalam menggambarkan

sistem. Dalam kasus pompa bensin paling sedikit ada tiga model yang dapat digunakan

\section{Langkah 3 : Gunakan formula matematik atau metode simulasi untuk menganalisa antrian.}

\section{Komponen dalam Sistem Antrian}

Lihat kembali struktur dari sistem antrian dalam Gambar 1 Sistem antrian memiliki beberapa komponen sebagai berikut:

1. Populasi masukan (input population). Beberapa banyak 
pelanggan potensi yang dapat memasuki sistem antrian ? Misalnya terdapat sepuluh mesin yang akan diperbaiki dengan satu orang tenaga mekanik. Ketika mesin mengalami kerusakan maka mesin akan antriuntuk diperbaiki oleh mekanik. Ratarata yang ada ketika sepuluh mesin dianggap sebagai populasi sedangkan perbaikan mesin dianggap sebagai fasilitas pelayanan, maka mesin tersebut akan kembali masuk sebagai populasi pelanggan potensial. Contoh seperti ini disebut input populasi terbatas (finite input population), karena jumlah mesin adalah terbatas atau tidak dapat dikatakan sebagai input tak terbatas.

Dalam prakteknya, setiap sistem antrian mempunyai populasi input yang terbatas. Jika menghadapi populasi pelanggan potensial yang cukup besar, maka hal itu dapat dikatakan sebagai input populasi tak terbatas (finite input population). Suatu populasi dapat dikatakan besar apabila populasi tersebut lebih besar dibandingkan dengan kapasitas sistem pelayanan. Misalnya, dalam kasus SPBU, jika jumlah kendaraan yang ada di kota tersebut sebanyak 20.000 kendaraan, maka populasi tersebut dapat dikatakan relatif besar, jika dibandingkan dengan kapasitas pelayanan (tiga buah pompa).

2. Distribusi

kedatangan. Menggambarkan bagaimana distribusi pelanggan memasuki sistem disebut distribusi kedatangan (arrival distribution). Para pelanggan mungkin dapat setiap lima menit (constant arrival distribution), atau mungkin datang secara acak (arrival pattern random). Dengan demikian terdapat dua cara pola kedatangan (arrival pattern) yaitu:menggambarkan jumlah kedatangan perunit waktu atau menggambarkan jumlah kedatangan dalam periode waktu tertentu berturut-turut dalam waktu yang berbeda.
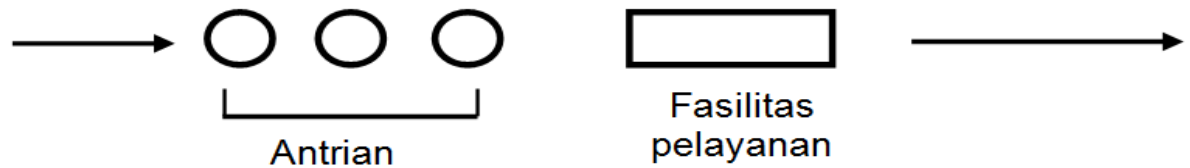

\section{Gambar 3. Sistem Single Channel}

3. Disiplin pelayanan. Disiplin pelayanan menunjukkan pelanggan yang mana yang akan dilayani lebih dulu. Pedoman yang umum digunakan dalam disiplin pelayanan adalah FCFS (first come, first served) atau yang pertama datang, pertama dilayani, 
dan LDFS (Last come, first served) atau terakhir datang, pertama dilayani, dan LDFS (Last come, first served) atau terakhir datang, pertama dilayani. Disamping itu pelanggan mungkin juga dilayani secara acak dan mungkin juga dilayani berdasarkan prioritas, seperti dalam ruang gawat darurat (RGD) sebuah rumah sakit, pasien yang datang dalam keadaan patah kaki akan diprioritaskan untuk dilayani ketimbang pasien yang luka memar.

4. Fasilitas pelayanan. Fasilitas pelayanan adalah mengelompokkan fasilitas pelayanan menurut jumlah yang tersedia. Sistem single-channel merupakan sistem yang terdiri dari suatu saluran untuk memasuki sistem pelayanan dengan satu fasilitas pelayanan, seperti ditunjukkan dalam Gambar 3.

Dalam model kasus SPBU (pompa bensin) seperti ditunjukkan dalam Gambar 2, merupakan contoh yang menggunakan sistem multiple channel (mempunyai tiga saluran). Sistem multiple channel terdiri dari satu antrian dengan dua atau lebih fasilitas pelayanan. Seorang pelanggan dapat dilayani oleh siapapun kemudian keluar dari sistem.

5. Distribusi pelayanan. Distribusi pelayanan dapat diterapkan berdasarkan salah satu dari berikut ini : (1) Berapa banyak pelanggan yang dapat dilayani per satuan waktu. Atau (2) Berapa lama setiap pelanggan dapat dilayani. Dalam kasus yang lain, suatu distribusi probabilitas mungkin digunakan untuk menentukan rata-rata waktu pelayanan.

6. Kapasitas sistem pelayanan. Kapasitassistem pelayanan sama dengan memaksimumkan jumlah pelanggan yang diperkenankan masuk dalam sistem. Kapasitas sistem mungkin terbatas atau mungkin juga tidak terbatas.

7. Karakteristik sistem lainnya. Dalam praktek sistem antrian para pelanggan tidak akan memasuki antrian pelanggan lain telah banyak yang menunggu, dengan kata lain mungkin pelanggan akan meninggalkan antrian. Kita mungkin memiliki pengalaman, akan meninggalkan supermarket apabila tempat parkir sudah penuh. Sesuai lain yang menyebabkan mengapa pelanggan setelah masuk dalam antrian, kemudian memilih untuk meninggalkan antrian sebelum menerima pelayanan. Perilaku seperti ini dikatakan sebagai reneging atau pengingkaran.

Notasi dalam Sistem Antrian.

Notasi berikut ini merupakan notasi yang akan digunakan dalam menggambarkan sistem antrian yaitu : $\mathrm{n}=$ Jumlah pelanggan dalam sistem

Pn = Probabilitas kepastian pelanggan dalam sistem

$\lambda=$ Jumlah rata-rata pelanggan yang datang persatuan waktu

$\mu=$ Jumlah rata-rata pelanggan yang dilayani persatuan waktu

Po = Probabilitas tidak ada pelanggan dalam sistem

$\mathrm{P}=$ Tingkat intensitas fasilitas pelayanan 
$\mathrm{L}=$ Jumlah rata-rata pelanggan yang diharapkan dalam sistem

$\mathrm{Lq}=$ Jumlah pelanggan yang diharapkan menunggu dalam antrian

$\mathrm{W}$ = Waktu yang diharapkan oleh pelanggan selama dalam sistem

$\mathrm{Wq}=$ Waktu yang diharapkan oleh pelanggan selama menunggudalam antrian

$1 / \mu=$ Waktu rata-rata pelayanan

$1 / \lambda=$ Waktu rata-rata antar kedatangan

$\mathrm{S}=$ Jumlah fasilitas pelayanan.

\section{SINGLE - CHANNEL MODEL}

Salah satu model antrian yang paling sederhana adalah modelsaluran tanggal (Single-channel model) yang ditulis dengan notasi "sistemM/M/1". Komponen dari sistem ini adalah sebagai berikut:

1. Populasi input tak terbatas yaitu jumlah kedatangan pelanggan potensial tak terbatas.

2. Distribusi kedatangan pelanggan potensial mengikuti distribusi Poisson. Rata-rata jumlah kedatangan pelanggan per satuan waktu adalah variabel random suatu distribusi probabilitas Poison. Dalam notasi "M/M/1", tanda M pertama menunjukkan rata-rata kedatangan yang mengikuti distribusi probabilitas Poisson. Sedangkan arti M yang kedua adalah menunjukkan tingkat pelayanan yang mengikuti distribusi probabilitas Poisson. Sedangkan arti $M$ yang kedua adalah menunjukkan tingkat pelayanan yang mengikuti distribusi probabilitas Poisson. Angka satu menunjukkan jumlah fasilitas pelayanan dalam sistem atau satusaluran (one channel).

3. Disiplin pelayanan mengikuti pedoman FCFS (Firstcome, First served).

4. Fasilitas pelayanan terdiri dari saluran tunggal.

5. Distribusi pelayanan juga mengikuti distribusi Poisson. Diasumsikan bahwa lamda lebih kecil dari miu $(\lambda<\mu)$ yaitu rata-rata jumlahkedatangan pelanggan persatuan waktu lebih kecil dari rata-rata jumlah pelanggan yang dapat dilayani per satuan waktu dalam sistem.

6. Kapasitas sistem diasumsikan tak terbatas.

7. Tidak ada penolakan maupun pengingkaran.

Persamaan yang digunakan dalam sistem (M/M/1) dapat dilihat sebagai berikut:

1. $p 1=\frac{\lambda}{\mu}$

(1a)

2. $P n=p^{n}(1-p)$

(1b)

3. $L=\frac{P}{1-p}=\frac{\lambda}{\mu-\lambda}$

(1c)

4. $L q=\frac{\lambda^{2}}{\mu(\mu-\lambda)}=\frac{P^{2}}{1-0}$

(1d)

5. $W=\frac{1}{\mu-\lambda}$

(1e)

6. $W q=\frac{\lambda}{\mu(\mu-\lambda)}$ 
Contoh 1 model (M/M/1) Kasus Pompa Bensin (SPBU)

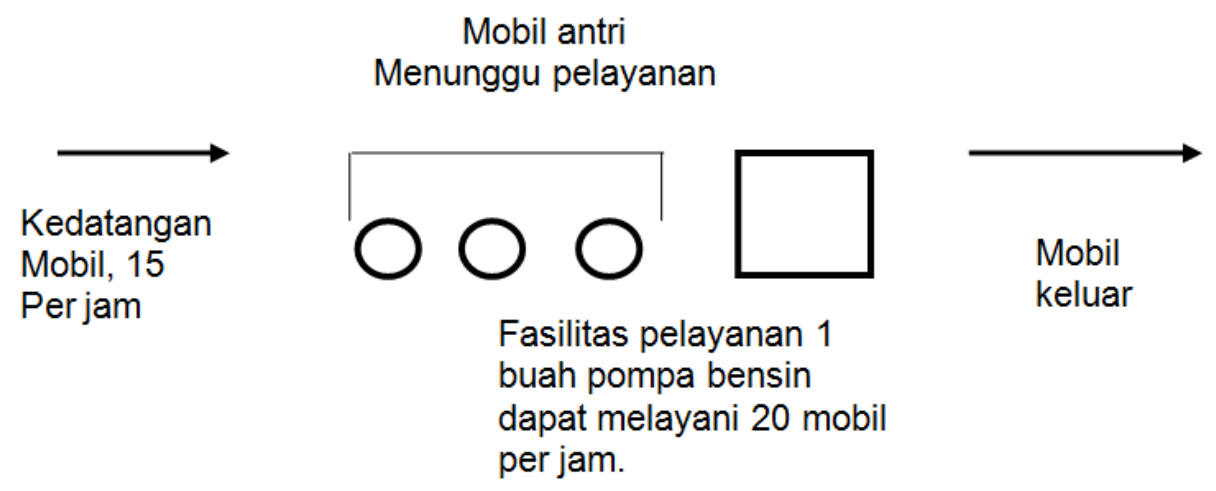

Gambar 4. SPBU PT. SGT Sistem Antrian (M/M/1)

PT. SGT mengoperasikan satu buah pompa bensin dengan satu orang operator yang bernama John, seperti diperlihatkan dalam Gambar 4 berikutini:

Rata-rata tingkat kedatangan kendaraan mengikuti distribusi poisson yaitu 20 kendaraan/mobil per jam. John dapat melayani rata-rata 25 mobil per jam, dengan waktu pelayanan setiap mobil mengikuti distribusi probabilitas eksponensial. Jika diasumsikan model sistem antrian yang digunakan Johnadalah (M/M/1), hitunglah soal-soal berikut ini untuk Johm.

1. Tingkat intensitas (kegunaan) pelayanan (p).

2. Jumlah rata-rata kendaraan yang diharapkan dalam sistem

3. Jumlah kendaraan yang diharapkan oleh setiap kendaraan selama dalam sistem (menunggu pelayanan).

4. Waktu yang diharapkan oleh setiap kendaraan untuk menunggu dalam antrian.

\section{Penyelesaian.}

Dari kasus di atas, kita memiliki $\lambda=20$ dan $\mu=25$

1. Tingkat intensitas (kegunaan) pelayanan atau $\mathrm{p}$

$$
p=\frac{\lambda}{\mu}=\frac{20}{25}=0,80
$$

Angka tersebut menunjukkan John akan sibuk melayani mobil selama $80 \%$ dari waktunya. Sedangkan $20 \%$ dari waktunya atau $(1-p)$ atau $(1-0,80)$ yang sering disebut idle time akan digunakan John untuk istirahat, membersihkan pompa dan Iain-Iain.

2. $p=\frac{\lambda}{\mu-\lambda}=\frac{20}{25-20}=4$, atau

$L=\frac{P}{1-p}=\frac{0,80}{1-1,80}=4 \quad$ (lihat persamaan 1c)

Angka 4 menunjukkan bahwa John akan mengharapkan 4 mobil yangberada dalam sistem.

3. $L q=\frac{\lambda^{2}}{\mu(\mu-\lambda)}=\frac{(20)^{2}}{25(25-20)}=$ $\frac{400}{125}=3,20$

Angka tersebut menunjukkan bahwa, mobil yang menunggu 
untuk dilayani dalam antrian sebanyak3,20 kendaraan.

4. $W=\frac{1}{\mu-\lambda}=\frac{1}{25-20}=\frac{1}{5}=$

0,20 jam atau 12 menit

Angka tersebut menunjukkan bahwa, waktu rata-rata kendaraan menunggu dalam sistem selama 12 menit.

5. $W q=\frac{1}{\mu(\mu-\lambda)}=\frac{20}{25(25-20)}=$ $\frac{20}{125}=0,16$ jam atau 9,6 menit

Angka tersebut menunjukkan bahwa, waktu rata-rata kendaraan menunggu dalam antrian selama 9,6 menit.

Untuk menunggu persamaan (13-1b) yaitu probabilitas kapasitas jumlah kendaraan yang ada dalam sistem, dihitung dengan menjumlahkan Po + $\mathrm{P} 1+\mathrm{p} 3+\mathrm{P} 4$ di mana $\mathrm{Pn}=\mathrm{P}^{\mathrm{a}}(1-\mathrm{p})$ atau

$$
\begin{aligned}
\operatorname{Pn}= & (0,80)^{\mathrm{n}}(1-0,80) \\
= & (0,80)^{\mathrm{n}}(0,20)
\end{aligned}
$$

Hasil perhitungan $\mathrm{Pn}$ adalah sebagai berikut :

Perhitungan tersebut menunjukkan bahwa, tingkat probabilitas 4 mobil berada dalam sistem pelayanan adalah sebesar $67,20 \%$

Dalam setiap sistem antrian distribusi Poisson, akan selalu terjadi hubungan yang berkait antara L, Lq, W, dan Wq. Hubungan tersebut dapat dinyatakan dalam persamaan berikut :

$$
\begin{aligned}
& \mathrm{L}=\lambda \mathrm{W} \\
& \mathrm{Lq}=\lambda \mathrm{Wq} \\
& \mathrm{W}=\mathrm{Wq}+1 / \mu
\end{aligned}
$$

Persamaan di atas dapat dicek dengan persamaan yang terdapat dalam sistem (M/M/1). Misalnya, persamaan (2). Jika persamaan (1e) dikalikan dengan lamda $(\lambda)$, maka akan diperoleh hasil sebagai berikut:

$$
W=\left(\frac{1}{\mu-\lambda}\right),
$$

yaitu persamaan $(-1 c)$

$$
\lambda W=\lambda\left(\frac{1}{\mu-\lambda}\right)=\frac{\lambda}{\mu-\lambda}=L
$$

Dari hasil pengecekan tersebut, apakah kita akan menggunakan persamaan 2,3, maupun 4 di atas ? Jika kita mengetahui salah satu nilai dari keempat parameter L, Lq, W, atau Wq, maka kita dapat menyelesaikan masalah dengan menggunakan ketiga persamaan di atas.

Misalnya kita mempunyai sistem (M/M/1) dengan $\lambda=20 \operatorname{dan} \mu=25$ (lihat kembali contoh 1). Dari persamaan ( $1 \mathrm{e} 0$ kita dapat menghitung W sebagai berikut :

$$
\begin{aligned}
W=\left(\frac{1}{\mu-\lambda}\right) & =\frac{\lambda}{25-20} \\
& =0,20
\end{aligned}
$$

Di samping itu, kita dapat menghitung L, Lq, dan Wq, dengan menggunakanpersamaan (1c), (1d), dan (1f) seperti yang terdapat dalam contoh 1. Namundemikian, kita dapat menggunakan persamaan (3) dan (4) untuk menghitungketiga parameter tersebut.

Jika kita telah mengetahui nilai W, maka kita dapat menggunakanpersamaan (4) untuk menemukan nilai $\mathrm{Wq}$.

$$
\begin{aligned}
& W q=W-\frac{1}{\mu}=0,20-\frac{1}{25}= \\
& 0,20-0,04=0,16 \mathrm{jam}
\end{aligned}
$$

Dengan diketahuinya nilai $\mathrm{Wq}$, kita dapat menggunakan persamaan (3) untuk menemukan nilai Lq.

$$
\mathrm{Lq}=\lambda \mathrm{Wq}=20(0,16)=3,20
$$
kendaraan (mobil). Akhirnya kita juga dapat menggunakan persamaan (2) untuk menentukan nilai $\mathrm{L}$.

$$
\mathrm{L}=\lambda \mathrm{W}=20(0,20)=4
$$
kendaraan (mobil). 
Jika persamaan (4) dimasukkan ke dalam persamaan (2) maka akandiperoleh persamaan sebagai berikut:

$$
\begin{aligned}
L & =\lambda W=\lambda\left(W q+\frac{1}{\mu}\right)= \\
\lambda W q+\frac{2}{\mu} & =L q=p
\end{aligned}
$$

Di mana:

$$
\lambda \mathrm{Wq}=\mathrm{Lq} \operatorname{dan} \lambda / \mu=\mathrm{p}
$$

Jika $\mathrm{L}=$ Jumlah pelanggan yang diharapkan dalam sistem, maka : $L$

$=\left[\begin{array}{c}\text { Jumlah pelanggan yang } \\ \text { diharapkan dalam antrian }\end{array}\right]$ $+\left[\begin{array}{c}\text { Jumlah pelanggan yang } \\ \text { diharapkan dalam pelayaran }\end{array}\right]$

Sedangkan jumlah pelanggan yang diharapkan dalam pelayanan dapat ditulis dengan persamaan sebagai berikut:

$\left[\begin{array}{l}\text { Probabilitas tingkat } \\ \text { intensitas pelayanan }\end{array}\right]\left[\begin{array}{l}1 \text { pelanggan } \\ \text { Probabilitas }\end{array}\right]$

$$
+\left[\begin{array}{c}
\text { Probabilitas } \\
\text { idle time }
\end{array}\right][0 \text { pelanggan }]
$$$$
=\mathrm{P}(1)+(1-\mathrm{p})(0)=\mathrm{p}
$$

Dari perhitungan tersebut, akan diperoleh persamaan sebagai berikut:

$$
\mathrm{L}=\mathrm{Lq}=\mathrm{p}
$$

\section{KESIMPULAN}

Dari teori-teori dan praktek kenyataan di lapangan yang terjadi sehari- hari dapat kita tarik kesimpulan bahwa sistem antrian ini sangat diperlukan dan sangat membantu masyarakat mendapatkan pelayanan jasa lebih cepat dan adil serta yang tak kalah pentingnya adalah untuk meningkatkan/ menegakkan kedisiplinan pada masyarakatkita. Semua ini sangat penting untuk menuju masyarakat pergaulan yang maju dan modern seperti negara tetangga dekat kita yang telah demikian baiknya membudayakan budaya antri, yaitu Singapore.
Pada masalah pelayanan apa saja kita dapat melihat bahwa semua itudijalankan dengan sistem antrian dan kita akan merasa malu sendiri jika tidak ikut pada barisan antri yang telah ditentukan. Dan lebih penting lagi mereka berani menegor jika seseorang tidak berdiri pada garis antrian yang telah ditentukan.

Semoga tulisan yang demikian sedikit dapat menggerakkan hati kita untuk memulai dari diri sendiri agar budaya antri itu kita patuhi, dengan ataupun tanpa dilihat oleh petugas pengawas antrian.

\section{DAFTAR PUSTAKA}

T.Hani Handoko. 2000. Manajemen. Edisi Kedua. Yogyakarta: BPFE Yogyakarta

Subiyanto, I (2000). Metodologi Penelitian. Edisi 3. Yogyakarta: UPP AMP YKPN.

Subana, M dan Sudrajat (2001). Dasar-dasar Penelitian Ilmiah. Bandung: CV. Pustaka Pelajar.

Alfabeta Ma'arif dan Tanjung. 2003. Manajemen Produksi dan Operasi. Edisi Revisi. Jakarta: Fakultas Ekonomi Universitas Jakarta

Syamsul M dan Hendri T (2003). Manajemen Operasi. Edisi Pertama. Jakarta: PT. Grasindo.

Tampubolon, Manahan P (2004). Manajemen Operasional (Operational Management). Jakarta: Salemba Empat.

Tampubolon, Manahan P. 2004. Manajemen Operasional. Jakarta: PT. Ghalia Indonesia. 